Supporting Information for:

\title{
Photosensitization via Dye Coordination: A New Strategy to Synthesize Metal Nitrosyls that Release NO under Visible Light
}

\author{
Michael J. Rose ${ }^{\dagger}$, Marilyn M. Olmstead ${ }^{\ddagger}$, and Pradip K. Mascharak ${ }^{\dagger *}$ \\ ${ }^{\dagger}$ Department of Chemistry and Biochemistry, University of California, Santa Cruz; \\ ${ }^{\ddagger}$ Department of Chemistry, University of California, Davis
}

Materials and Reagents. Commercially available $\mathrm{RuCl}_{3} \bullet x \mathrm{H}_{2} \mathrm{O}$ was used to prepare $\mathrm{RuCl}_{3} \cdot 3 \mathrm{H}_{2} \mathrm{O}$. ${ }^{1}$ The ligands $\mathrm{H}_{2} \mathrm{Me}_{2} \mathrm{bpb}$ and $\mathrm{H}_{2} \mathrm{Me}_{2} \mathrm{bQb}$, as well as precursor complexes $\left[\left(\mathrm{Me}_{2} \mathrm{bpb}\right) \mathrm{Ru}(\mathrm{NO})(\mathrm{Cl})\right]$ and $\left[\left(\mathrm{Me}_{2} \mathrm{bQb}\right) \mathrm{Ru}(\mathrm{NO})(\mathrm{Cl})\right]$ were synthesized as previously reported. ${ }^{1}$ NO gas was supplied by Spectra Gases and purified as previously described. ${ }^{1}$

Syntheses. [(Me $2 \mathbf{b p b}) \mathbf{R u}(\mathbf{N O})(\operatorname{Resf})](\mathbf{1})$. A batch of $0.200 \mathrm{~g}(0.391 \mathrm{mmol})$ of $\left[\left(\mathrm{Me}_{2} \mathrm{bpb}\right) \mathrm{Ru}(\mathrm{NO})(\mathrm{Cl})\right]$ was slurried in $20 \mathrm{~mL}$ of $\mathrm{MeCN}$ and treated with $\mathrm{AgBF}_{4}(0.076$ $\mathrm{g}, 0.391 \mathrm{mmol}$ ) dissolved in $5 \mathrm{~mL}$ of $\mathrm{MeCN}$. This mixture was refluxed $12 \mathrm{~h}$ to generate a turbid brown-green solution, which was cooled to room temperature and filtered through a Celite pad to remove $\mathrm{AgCl}$. One equivalent $(0.101 \mathrm{~g}, 0.391 \mathrm{mmol})$ of the Resorufin dye (as sodium salt) was then added, and the reaction refluxed another $16 \mathrm{~h}$ to generate a bright red solution. This mixture was cooled to $-20^{\circ} \mathrm{C}$ overnight and filtered to remove trace amounts of excess dye. The filtrate was concentrated to one-third volume and again placed at $-20^{\circ} \mathrm{C}$ to afford complex $\mathbf{1}$ as a bright red solid. Yield: 117

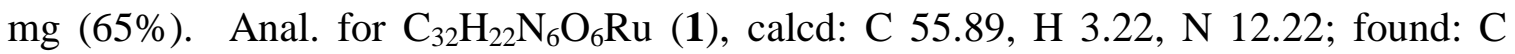
56.10, H 3.28, N 12.14. For Selected IR frequencies $\left(\mathrm{KBr}\right.$ pellet, $\left.\mathrm{cm}^{-1}\right)$ : $1841 \mathrm{vs}\left(\mathrm{v}_{\mathrm{NO}}\right)$, 
1632 vs $\left(v_{\mathrm{CO}}\right), 1595$ vs, $1484 \mathrm{~s}, 1367 \mathrm{~m}, 1276 \mathrm{~s}\left(\mathrm{v}_{\mathrm{ArCO}}\right), 1206 \mathrm{w}, 1097 \mathrm{w}, 864 \mathrm{w}, 759 \mathrm{w}$, 685 w. Electronic spectrum in $\mathrm{MeCN}, \lambda \mathrm{nm}\left(\varepsilon: \mathrm{M}^{-1} \mathrm{~cm}^{-1}\right): 237 \mathrm{sh}(16180), 280$ (11 860), 307 sh (6 680), 395 sh (5 940) 500 (11 920). ${ }^{1} \mathrm{H}-\mathrm{NMR}$ in $\mathrm{CDCl}_{3}, \delta$ from TMS: 8.81 $\mathrm{d}(2 \mathrm{H}), 8.39 \mathrm{~s}(2 \mathrm{H}), 8.35 \mathrm{~d}(2 \mathrm{H}), 8.25 \mathrm{t}(2 \mathrm{H}), 7.77 \mathrm{t}(2 \mathrm{H}), 7.30 \mathrm{~d}(2 \mathrm{H}), 7.12 \mathrm{~d}(2 \mathrm{H}), 6.74 \mathrm{~d}$ $(1 \mathrm{H}), 6.15 \mathrm{~s}(1 \mathrm{H}), 5.93 \mathrm{~d}(1 \mathrm{H}), 5.62 \mathrm{~d}(1 \mathrm{H}), 2.93 \mathrm{~s}(6 \mathrm{H})$.

$\left[\left(\mathbf{M e}_{2} \mathbf{b p b}\right) \mathbf{R u}(\mathbf{N O})(\mathbf{O H})\right](\mathbf{2})$. A batch of $\left[\left(\mathrm{Me}_{2} \mathrm{bpb}\right) \mathrm{Ru}(\mathrm{NO})(\mathrm{Cl})\right](0.200 \mathrm{~g}, 0.391 \mathrm{mmol})$ was treated with $\mathrm{AgBF}_{4}$ in $\mathrm{MeCN}$ under reflux conditions as described above. Following filtration, several drops of water and three equivalents of aniline $(0.109 \mathrm{~g}, 1.17 \mathrm{mmol})$ were added to make the reaction mixture basic. This solution was refluxed $16 \mathrm{~h}$ to generate a pale orange color. Concentration of this solution to $\sim 5 \mathrm{~mL}$ and stirring at room temperature for several hours precipitated pure $\mathbf{2}$ as orange solid. Yield: $105 \mathrm{mg}$ (55\%). Anal. for $\mathrm{C}_{20} \mathrm{H}_{17} \mathrm{~N}_{5} \mathrm{O}_{4} \mathrm{Ru}$ (2), calcd: C 48.78, H 3.48, N 14.22; found: C 48.62, H 3.55, N 14.03. Selected IR frequencies $\left(\mathrm{KBr}\right.$ pellet, $\left.\mathrm{cm}^{-1}\right)$ : $1828 \mathrm{~s}\left(v_{\mathrm{NO}}\right), 1621 \mathrm{~s}\left(v_{\mathrm{CO}}\right)$, 1587 s, 1564 m, 1483 m, 1388 m, 1364, 1097 w, 1008 w, 758 m, 685 m, 485 w. Electronic spectrum in DMF, $\lambda \mathrm{nm}\left(\varepsilon: \mathrm{M}^{-1} \mathrm{~cm}^{-1}\right): 304$ (7 020), 390 (5 100). ${ }^{1} \mathrm{H}-\mathrm{NMR}$ in DMSO, $\delta$ from TMS: $9.13 \mathrm{~d}(2 \mathrm{H}), 8.34 \mathrm{~m}(2 \mathrm{H}), 8.32 \mathrm{~s}(2 \mathrm{H}) 8.13 \mathrm{~d}(2 \mathrm{H}), 7.85 \mathrm{~m}(2 \mathrm{H})$, $3.34 \mathrm{~s}(6 \mathrm{H})$.

$\left[\left(\mathbf{M e}_{2} \mathbf{b Q b}\right) \mathbf{R u}(\mathbf{N O})(\mathbf{R e s f})\right](\mathbf{3})$. To a slurry of $\left[\left(\mathrm{Me}_{2} \mathrm{bQb}\right) \mathrm{Ru}(\mathrm{NO})(\mathrm{Cl})\right](0.100 \mathrm{~g}, 0.165$ mmol) in $\mathrm{MeCN}(20 \mathrm{~mL})$ was added one equiv of $\mathrm{AgBF}_{4}(0.032 \mathrm{~g}, 0.165 \mathrm{mmol})$ to generate a turbid brown solution after $16 \mathrm{~h}$ of heating at $\sim 85^{\circ} \mathrm{C}$. This mixture was filtered through Celite to remove $\mathrm{AgCl}$. Next, one equiv of Resorufin sodium salt ( 0.040 
$\mathrm{g}, 0.166 \mathrm{mmol}$ ) was added. The slurry was heated at reflux temperature for an additional $16 \mathrm{~h}$ to afford a bright red solution that was hot-filtered to remove trace amounts of unreacted dye. The filtrate was then was concentrated to $\sim 5 \mathrm{~mL}$ and stored at $-20^{\circ} \mathrm{C}$ for several days. Red microcrystalline material was collected and washed several times with THF, then $\mathrm{Et}_{2} \mathrm{O}$ to afford pure 3. Yield: $32 \mathrm{mg}(35 \%)$. Anal. for $\mathrm{C}_{40} \mathrm{H}_{26} \mathrm{~N}_{6} \mathrm{O}_{6} \mathrm{Ru}(3)$, calcd: C 60.99, H 3.33, N 10.67; found: C 60.72, H 3.48, N 10.89. Selected IR frequencies $\left(\mathrm{KBr}\right.$ pellet, $\left.\mathrm{cm}^{-1}\right): 1847 \mathrm{~s}\left(\mathrm{v}_{\mathrm{NO}}\right), 1631 \mathrm{vs}\left(\mathrm{v}_{\mathrm{CO}}\right), 1585 \mathrm{~s}, 1558 \mathrm{~m}, 1485 \mathrm{~m}$, $1368 \mathrm{~m}, 1281 \mathrm{~s}\left(\mathrm{v}_{\mathrm{ArCO}}\right), 798 \mathrm{w}, 462 \mathrm{w}$. Electronic spectrum in $\mathrm{MeCN}, \lambda \mathrm{nm}\left(\varepsilon: \mathrm{M}^{-1} \mathrm{~cm}^{-}\right.$ $\left.{ }^{1}\right): 300(16900), 510(12300) .{ }^{1} \mathrm{H}-\mathrm{NMR}$ in $\mathrm{CDCl}_{3}, \delta$ from TMS: $8.74 \mathrm{~d}(2 \mathrm{H}), 8.54 \mathrm{~d}$ $(2 \mathrm{H}), 8.37 \mathrm{~s}(2 \mathrm{H}), 8.14 \mathrm{~d}(4 \mathrm{H}), 7.80 \mathrm{t}(2 \mathrm{H}), 7.55 \mathrm{t}(2 \mathrm{H}), 7.35 \mathrm{~m}(1 \mathrm{H}), 7.10 \mathrm{~d}(1 \mathrm{H}), 6.72 \mathrm{~d}$ (1H), $6.09 \mathrm{~s}(1 \mathrm{H}), 6.03 \mathrm{~d}(1 \mathrm{H}), 5.69 \mathrm{~s}(1 \mathrm{H})$.

X-ray Diffraction and Structure Solution Refinement. Diffraction data for $\mathbf{1}$ and $\mathbf{2}$ were collected at $90 \mathrm{~K}$ on a Bruker Apex II instrument using $\operatorname{MoK} \alpha$ radiation $(\lambda=$ $0.71073 \AA$ ) and the data were corrected for absorption. Structures were solved using the standard SHELXLS-97 package.

Photolysis Experiments. The rates of NO release were measured using $\sim 0.1 \mathrm{mM}$ solutions of the complexes in a $4 \mathrm{~mm} \times 10 \mathrm{~mm}$ cuvette. An IL 410 Illumination System from Electro-FiberOptics Corp (Halogen lamp) equipped with a $\geq 455 \mathrm{~nm}$ cutoff filter (measured output intensity $=300 \mathrm{~mW}$ ) was used. For UV photolysis of $\mathbf{2}$, solutions were exposed to low-intensity UV light $\left(7 \mathrm{~mW} / \mathrm{cm}^{2}\right.$, UV Transilluminator). The kinetics of NO release were monitored at an appropriate wavelength for each complex, and the NO 
releasing rates were derived from the 2-parameter exponential equation $y=a^{*}(1-\exp (-$ $\left.k^{*} x\right)$ ) as provided in SigmaPlot 8.0. Quantum yield $(\phi)$ measurements were performed using monochromatic light at $500 \mathrm{~nm}$ generated from an Apex Illuminator (150 W Xenon lamp) equipped with a Cornerstone $1301 / 8 \mathrm{M}$ monochromator (measured intensity of 9 $\mathrm{mW}$ at $500 \mathrm{~nm}$ ). Quantum yields in the UV range were determined using standard ferrioxalate actinometry, ${ }^{2}$ while Actinochrome N (475/610) was used as the standard in the visible range. ${ }^{3}$ Solutions were prepared at $\sim 0.2 \mathrm{mM}$ to ensure sufficient absorbance (>90\%) at the irradiation wavelength. For EPR experiments, a cuvette containing a $\sim 0.2$ $\mathrm{mM}$ solution of 1 were exposed to visible light $(\geq 455 \mathrm{~nm})$, while complex 2 was illuminated with UV light; solutions were then transferred to standard EPR sample tubes for analyses at $125 \mathrm{~K}$ (Bruker 500 ELEXYS spectrometer).

X-ray diffraction and Crystal Data. X-ray quality crystals of $\mathbf{1} \cdot \mathrm{H}_{2} \mathrm{O}$ were obtained by vapor diffusion of pentane into a solution of $\mathbf{1}$ in $\mathrm{CHCl}_{3}$ at $35^{\circ} \mathrm{C}$. Crystal Data for $\left[\left(\mathrm{Me}_{2} \mathrm{bpb}\right) \mathrm{Ru}(\mathrm{NO})(\mathrm{Resf})\right] \cdot \mathrm{H}_{2} \mathrm{O}\left(\mathbf{1} \bullet \mathrm{H}_{2} \mathrm{O}\right):$ Red needles of dimensions $0.22 \times 0.08 \times 0.07$ $\mathrm{mm}^{3}$ crystallized in space group $\mathrm{P} \overline{\mathrm{i}}$, with cell dimensions of $\mathrm{a}=10.0845(5) \AA, \mathrm{b}=$ 10.7797(6) $\AA, c=15.0195(8) \AA, \alpha=76.0570(10)^{\circ}, \beta=71.3960(10)^{\circ}, \gamma=69.1370(10)^{\circ}$; $Z=2, \rho_{\text {calc }}=1.638 \mathrm{Mg} / \mathrm{m}^{3}, \mu\left(\mathrm{Mo}_{\mathrm{K} \alpha}\right)=0.611 \mathrm{~mm}^{-1}$; total reflections were 24892 with 9957 independent reflections $[\mathrm{R}(\mathrm{int})=0.0392] ; \mathrm{min} . / \mathrm{max}$. transmission $=0.9585 / 0.8769$; $R 1=0.0348, \mathrm{w} R 2=0.0775[\mathrm{I}>2 \sigma(\mathrm{I})] ; R 1=0.0499, \mathrm{w} R 2=0.0839$ (all data).

X-ray quality crystals of $\mathbf{2}$.DMSO were grown from vapor diffusion of acetone into a biphasic $\mathrm{DMSO} \mathrm{Et}_{2} \mathrm{O}$ mixture at ambient temperature. Crystal Data for $\left[\left(\mathrm{Me}_{2} \mathrm{bpb}\right) \mathrm{Ru}(\mathrm{NO})(\mathrm{OH})\right] \cdot \mathrm{DMSO}(\mathbf{2} \cdot \mathrm{DMSO})$ : Red parallelepipeds of dimensions $0.22 \mathrm{x}$ 
$0.18 \times 0.09 \mathrm{~mm}^{3}$ crystallized in space group Pī, with cell dimensions $\mathrm{a}=9.6421(4) \AA, \mathrm{b}=$ 10.2603(4) $\AA, c=12.2844(5) \AA$ and angles $\alpha=75.430(3)^{\circ}, \beta=75.300(3)^{\circ}, \gamma=$ $89.954(3)^{\circ} ; Z=2, \rho_{\text {calc }}=1.669 \mathrm{Mg} / \mathrm{m}^{3}, \mu\left(\mathrm{Mo}_{\mathrm{K} \alpha}\right)=0.828 \mathrm{~mm}^{-1} ;$ total reflections were 14663 with 5198 independent reflections $[\mathrm{R}(\mathrm{int})=0.0184] ; \min . / \mathrm{max}$. transmission $=$ $0.929 / 0.839 ; R 1=0.0199, \mathrm{w} R 2=0.0522[\mathrm{I}>2 \sigma(\mathrm{I})] ; R 1=0.0213, \mathrm{w} R 2=0.0532$ (all data).

\section{References}

(1) Patra, A. K.; Rose, M. J.; Murphy, K. M.; Olmstead, M. M.; Mascharak, P. K. Inorg. Chem. 2004, 43, 4487.

(2) Murov, S. Handbook of Photochemistry. Marcel Dekker: New York, 1973.

(3) Schmidt, R.; Brauer, H.-D.; J. Photochem. 1984, 25, 489. 


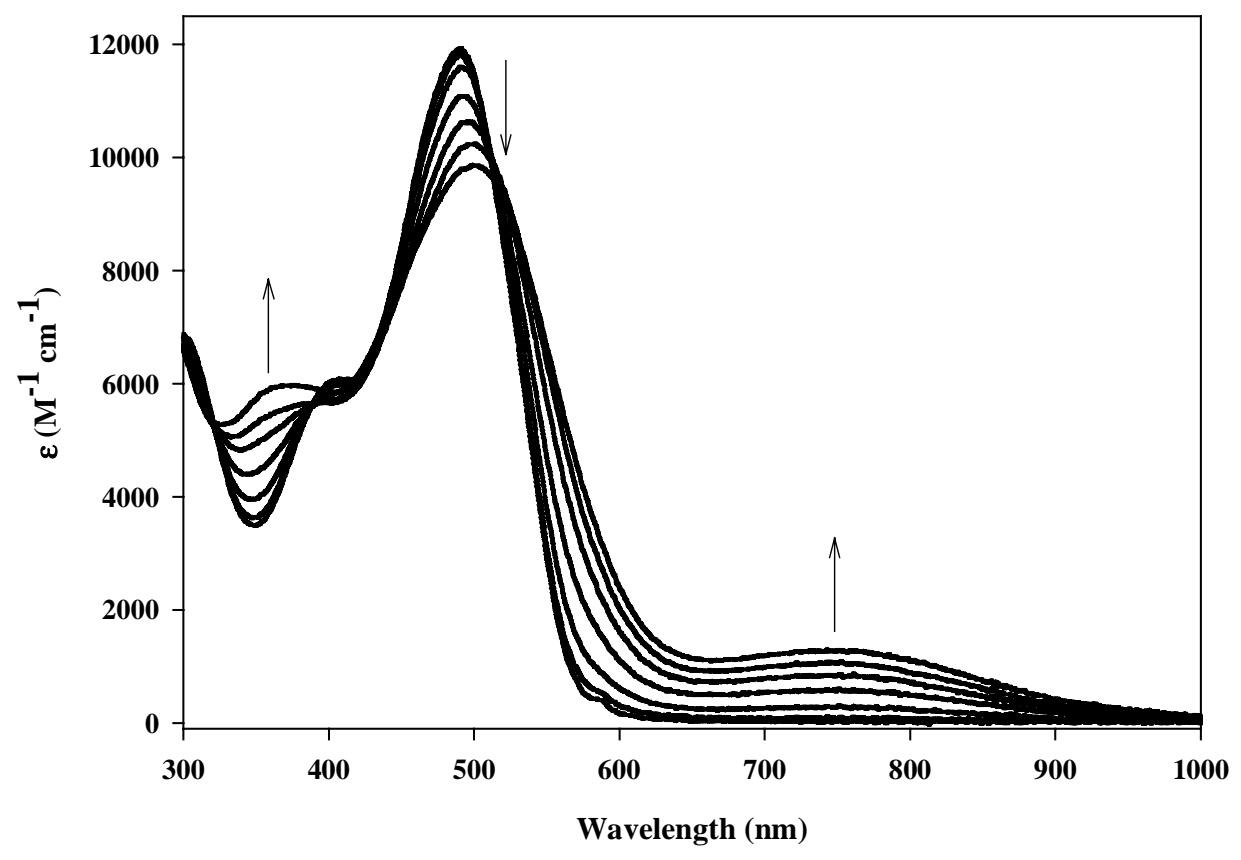

Figure S1. Changes in the electronic absorption spectrum of $\mathbf{1}$ in $\mathrm{H}_{2} \mathrm{O}$ observed upon photolysis with visible light $(\geq 455 \mathrm{~nm})$ for $\sim 20 \mathrm{~min}$. New peaks are generated at 360 and $750 \mathrm{~nm}$, and clean isosbestic points at 420 and $515 \mathrm{~nm}$ are observed.

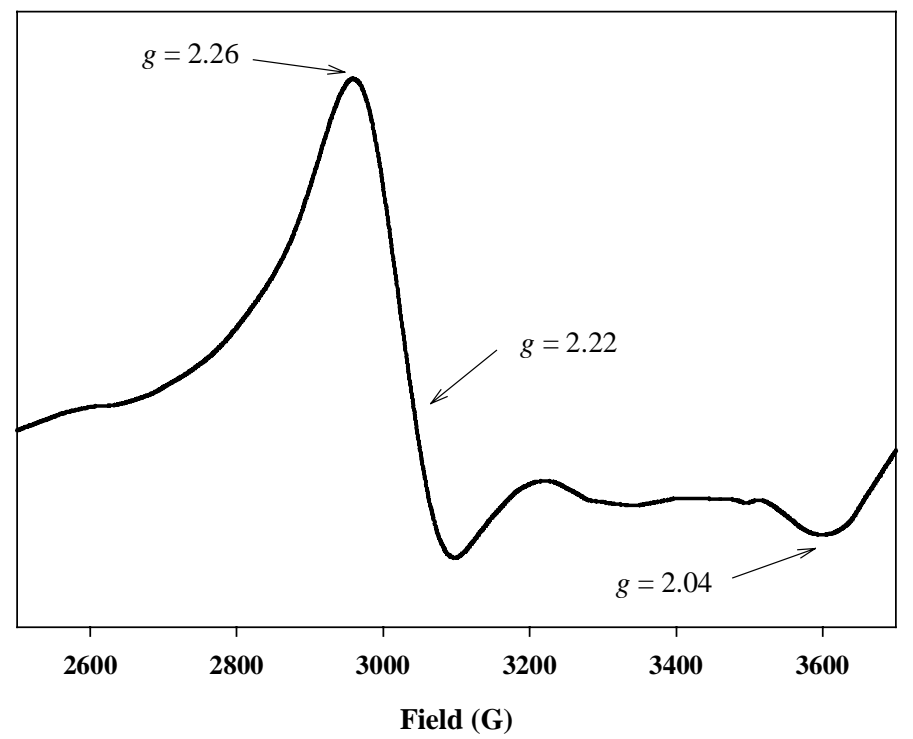

Figure S2. EPR spectrum of a photolyzed solution of $\left[\left(\mathrm{Me}_{2} \mathrm{bpb}\right) \mathrm{Ru}(\mathrm{NO})(\mathrm{Resf})\right](\mathbf{1})$ in frozen $\mathrm{H}_{2} \mathrm{O} /$ glycerol (20\% v/v) glass following exposure to visible light $(\geq 455 \mathrm{~nm})$. Instrument parameters: temperature, $125 \mathrm{~K}$; microwave power, $1 \mathrm{~mW}$; microwave frequency, $9.4 \mathrm{GHz}$; frequency modulation, $100 \mathrm{KHz}$. 

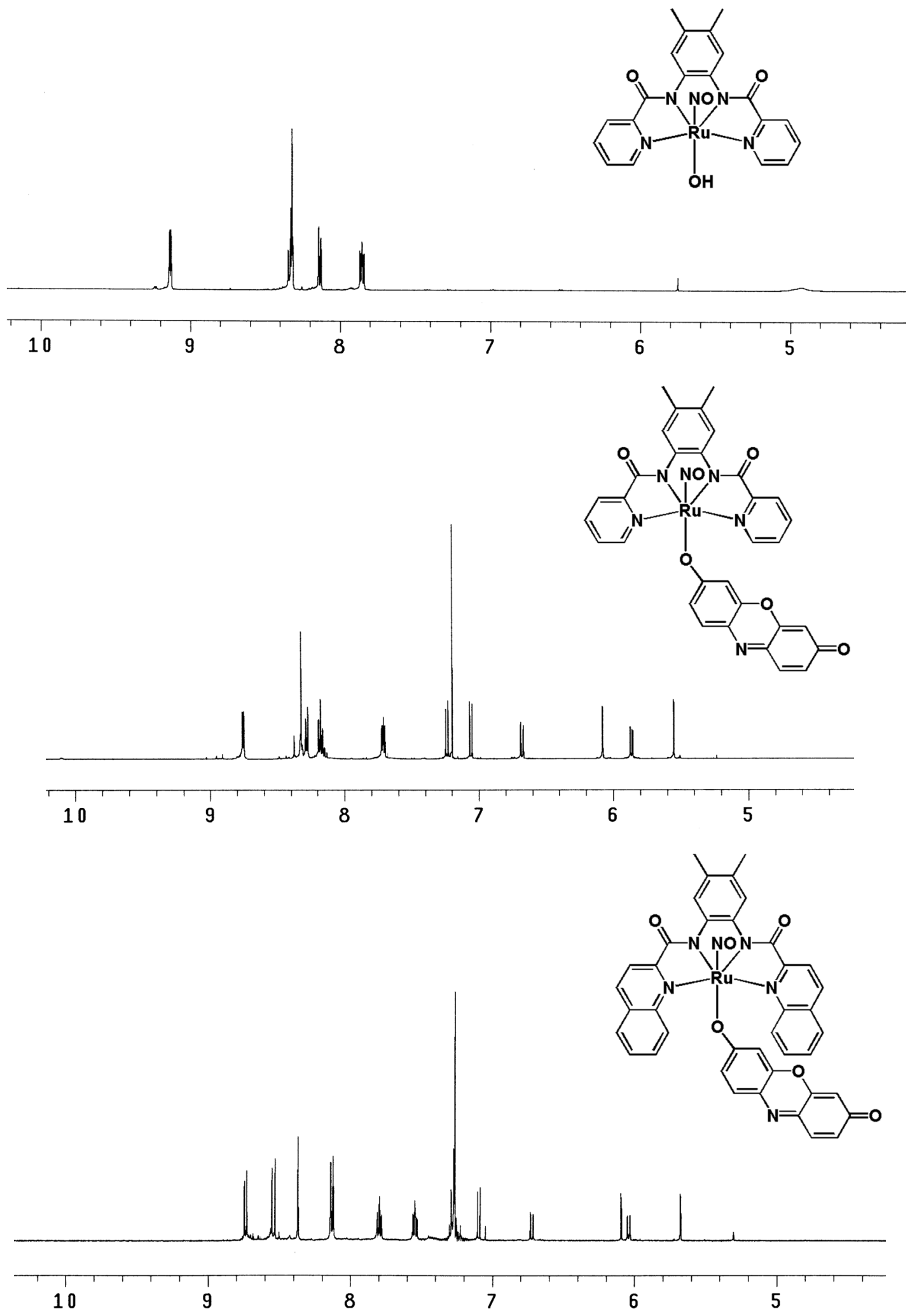

Figure S3. ${ }^{1} \mathrm{H}-\mathrm{NMR}$ spectra in the aromatic region of complexes 1-3 $(298 \mathrm{~K}, 500 \mathrm{MHz}$ Bruker spectrometer). Top: $\left[\left(\mathrm{Me}_{2} \mathrm{bpb}\right) \mathrm{Ru}(\mathrm{NO})(\mathrm{OH})\right](2)$ in $d^{6}$-DMSO. Middle: $\left[\left(\mathrm{Me}_{2} \mathrm{bpb}\right) \mathrm{Ru}(\mathrm{NO})(\mathrm{Resf})\right](\mathbf{1})$ in $\mathrm{CDCl}_{3}$. Bottom: $\left[\left(\mathrm{Me}_{2} \mathrm{bQb}\right) \mathrm{Ru}(\mathrm{NO})(\mathrm{Resf})\right](\mathbf{3})$ in $\mathrm{CDCl}_{3}$. 